\title{
Investigation of pollen morphological characteristics in some quince (Cydonia oblonga Mill.) cultivars
}

\author{
Aleksandar RADOVIĆ ${ }^{1{ }_{\star}}$, Dragan NIKOLIĆ ${ }^{1}$, Dragan MILATOVIĆ ${ }^{1}$, Dejan ĐUROVIĆ ${ }^{1}$, Jugoslav TRAJKOVIĆ \\ ${ }^{1}$ Faculty of Agriculture, University of Belgrade, Belgrade-Zemun, Serbia \\ ${ }^{2}$ The College of Agriculture and Food Technology, Prokuplje, Serbia
}

Received: 16.11 .2015

- $\quad$ Accepted/Published Online: 08.02.2016

Final Version: 18.05.2016

\begin{abstract}
Morphological characterization of pollen grains is very important in the identification of individual species and cultivars of fruit trees, including quince. As material for these studies, the pollen of eight quince cultivars, Leskovacka, Vranjska, Morava, Pazardzijska, Hemus, Asenica, Portugal, and Triumph was used. During the 3-year study period (2010-2012), using scanning electron microscopy (SEM), the following characteristics were investigated: the size and shape of pollen grains (length, width, and length-towidth ratio), colpus length, colpus width, mesocolpium width, and characteristics of exine pattern [number of ridges per area (100 $\mu \mathrm{m}^{2}$ ) at the equatorial region of exine, ridge width, and furrow width]. The tested quince cultivars differed significantly in terms of morphological characteristics of pollen. The exceptions were colpus and mesocolpium width, as well as the ridge and furrow width on the exine, which showed no statistically significant difference. Pollen grains of quince are characterized by great length (over $53 \mu \mathrm{m})$. The shape of pollen grains varied from prolate (Leskovacka, Vranjska, Morava, Hemus, Asenica, and Triumph) to perprolate (Pazardzijska and Portugal). The exine pattern of all cultivars was striate with longitudinal ridges, which were more parallel in cultivars Vranjska, Hemus, Portugal, and Triumph and less parallel in cultivars Leskovacka, Morava, Pazardzijska, and Asenica. Three groups of similar cultivars are separated on the basis of hierarchical cluster analysis results. Some pollen morphological characteristics, such as the size and shape of pollen grains and colpus length, can be used in the identification of quince cultivars.
\end{abstract}

Key words: Cultivar, Cydonia oblonga, exine, pollen grain, SEM

\section{Introduction}

Quince (Cydonia oblonga Mill.) is an old fruit species that has been grown for over 4000 years. It belongs to the family Rosaceae (rose), subfamily Maloideae (Pomoidae), (pome fruit). The subfamily Maloideae has about 1000 species and 30 genera, including the genus Cydonia, which has only the species of Cydonia oblonga Mill., with a large number of varieties (Bell and Leitao, 2011). Quince cultivars are divided into three groups on the basis of their fruit shape. They have apple-shaped (Cydonia oblonga var. maliformis), pear-shaped (Cydonia oblonga var. pyriformis), and bellshaped (Cydonia oblonga var. campanuloformis) fruits (Mratinić, 2010). According to some authors, within this species two further varieties can be distinguished: Cydonia oblonga var. piramidalis and Cydonia oblonga var. lusitanica.

In the production orchards of Serbia there are only two cultivars of quince: Leskovacka, the main cultivar, and Vranjska, its pollinator. Lately, new quince cultivars that achieve high yields per unit area and have good fruit quality with a high content of certain chemical components

*Correspondence: radovicaleksandar@yahoo.com (soluble solids, sugars, and acids) and excellent sensory properties (taste and aroma of the fruit) have been introduced into production. Before this introduction into production a detailed characterization and evaluation of these cultivars was carried out.

Quince has a bipolar (hermaphrodite) flower type. Stamens are composed of a large number of filaments (1520) and light yellow anthers, which are arranged in three circular rows. The pistil is made up of five fertile leaves (carpels) consisting of stigma, style, and ovary. Quince has yellow pollen grains. Shape and size of pollen often changes with variable air temperature and humidity and other environmental factors (Nagy-Dèri, 2011).

Research into the morphological characteristics of pollen is of great significance in taxonomy, phylogeny, and paleobotany because pollen grains have a definite shape, size, color, and structure for each species, genus, and family. Electron microscopy is a very powerful technique for testing the morphological characteristics of pollen in the various species of plants (Shivanna, 2003). Characteristics of pollen grains (size and shape of 
pollen grains and characteristics of exine) may be useful in identifying certain species and cultivars of fruit trees (Hebda et al., 1991). In addition, the form of pollen grains and protuberances on them play a very important role in the pollination of fruit trees, i.e. pollen transfer (either entomophilous or anemophilous) (Đokić, 1988).

The mature pollen grain wall consists of three layers: an outer wall (exine), an inner membrane (intine), and a pollen coat. The outer wall of pollen grains (exine) is multilayered and has a characteristic ornamentation. It is an extremely resistant structure comprising sporopollenin, a mixed polymer composed of fatty acids and phenolic components (Ríos et al., 2013). The inner membrane of the pollen grain (intine) is built primarily of cellulose. Pollen coat fills the sculptured cavities of the pollen exine and is composed of lipids, proteins, pigments, and aromatic compounds (Edlund et al., 2004).

The exine of pollen grains can be very significant for the characterization of cultivars of quince, as some differences between cultivars may occur in pollen grain width, ridge form, and number and size of perforates on the exine (Evrenosoğlu and Misırl, 2009). On the basis of the development of exine, the differences between male sterile and fertile genotypes can be determined, whereas in sterile genotypes microspores do not have fully developed exine, or have not achieved the typical morphology (Kaufmane and Rumpunen, 2002).

Analysis of the morphological characteristics of pollen by scanning electron microscopy (SEM) was performed for the identification and characterization of individual species and cultivars of apple (Currie et al., 1997; Joneghani, 2008), Japanese pear (Matsuta et al., 1982), quince (Evrenosoğlu and Misırl, 2009; Nagy-Dèri, 2011), plum (Geraci et al., 2012), peach (Radice et al., 2003; Hu et al., 2012), apricot (Dezhong et al., 1995; Arzani et al., 2005), sweet cherry (Gilani et al., 2010; Radičević et al., 2013), sour cherry (Nyéki et al., 1996; Miaja et al., 2000), almond (Talaie and Imani, 1998; Sorkheh et al., 2008), walnut (Lee et al., 2008; Mert, 2010), pistachio (Davarynejad et al., 1995), olive (Lanza et al., 1996; Lanza and Marsilio, 1999), cornelian cherry (Mert, 2009), and grapevine (İnceoğlu et al., 2000; Roytchev, 2009).

The aim of this study was to determine the morphology and ultrastructure of pollen in some cultivars of quince using scanning electron microscopy (SEM). This would help to identify cultivars, which is of great benefit for the certification of germplasm and breeding purposes.

\section{Materials and methods}

The studies were carried out in the collection orchard of quince at the experimental station, Radmilovac, of the Faculty of Agriculture in Belgrade, located $8 \mathrm{~km}$ northeast of Belgrade $\left(44^{\circ} 45^{\prime} \mathrm{N}, 20^{\circ} 35^{\prime} \mathrm{E}, 130 \mathrm{~m}\right.$ altitude). The orchard was planted in the spring of 1999 with plantings spaced at $4.5 \times 3 \mathrm{~m}$. The rootstock is quince MA, and the training system is modified central leader. The studies were conducted in the period from 2010 to 2012. The subjects of these studies were eight cultivars of quince, Leskovacka, Vranjska, Morava, Pazardzijska, Hemus, Asenica, Portugal, and Triumph.

For testing the morphological characteristics of pollen, flower buds were taken from the branches in the late balloon stage and transferred to the laboratory. In the laboratory, anthers were isolated from the flower buds in petri dishes and were maintained for $24-48 \mathrm{~h}$ at room temperature $\left(20 \pm 2{ }^{\circ} \mathrm{C}\right)$ to dry out in order to release their pollen. Then the petri dishes with pollen were transferred to a desiccator, where they were kept until analysis.

Preparation of pollen for analysis was performed by mounting two-layer transparent tape on the object carrier on the microscope and applying pollen with a brush. Coating of pollen samples was performed with a layer of gold (20 nm thickness) using Sputter-Coater BAL-TEC SCD 005 (Capovani Brothers Inc., Scotia, NY, USA). Observation of the prepared samples was carried out with a scanning electron microscope (SEM) JEOL JSM-6390LV (Tokyo, Japan) at a magnification of $2000 \times$ (whole grain) to $15,000 \times$ (exine pattern). In a sample of 30 pollen grains from each of the eight cultivars, the size and shape of pollen grains (length, width, and length-to- width ratio), colpus length, colpus width, and mesocolpium width and characteristics of exine pattern (number of ridges per 100 $\mu \mathrm{m}^{2}$ at the equatorial region of exine, ridge width, and furrow width) were examined. The experiment was done in three replicates. In each replicate, 10 pollen grains were analyzed.

Standard error for measured parameters was calculated. The mean value for thirty pollen grains \pm standard error was reported. Statistical analysis was performed using twofactorial analysis of variance (ANOVA). The significance of differences between the mean values was determined using Tukey's test for significance at $\mathrm{P}<0.05$. Clustering of quince cultivars into similarity groups was done using unweighted pair group average (UPGA) based on all tested characteristics. Data analysis was performed using the statistical software package STATISTICA, version 8 (StatSoft, Inc., Tulsa, OK, USA).

\section{Results and discussion}

Based on the analysis conducted by SEM, pollen grains of the quince cultivars tested can be characterized as isopolar and radially symmetric with three colpate apertures. Pollen grains in equatorial view are elliptical and in polar view are round (Figures 1-2).

The investigated quince cultivars differed significantly according to the size and shape of pollen grains. Thus, 
RADOVIĆ et al. / Turk J Agric For

a
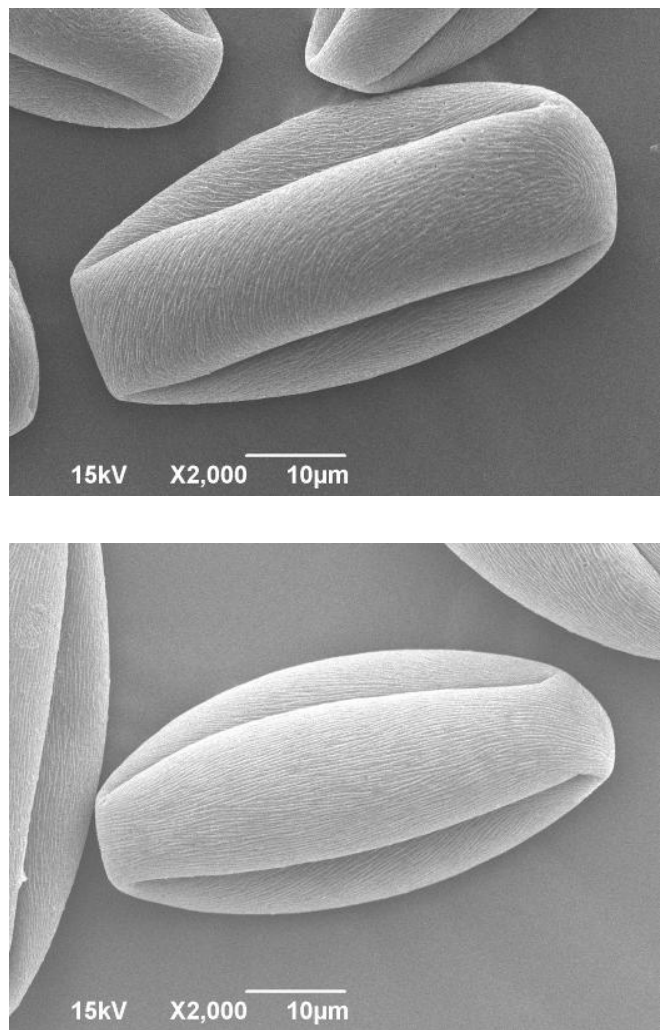

$\mathrm{b}$

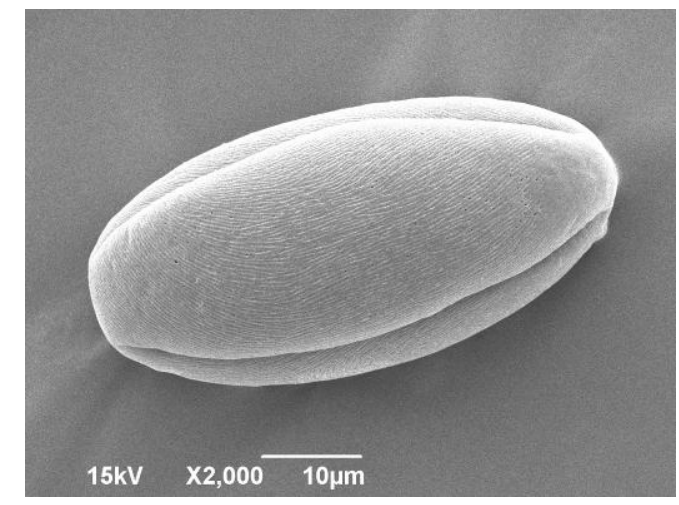

$15 \mathrm{kV} \times 2,000 \overline{10 \mu \mathrm{m}}$

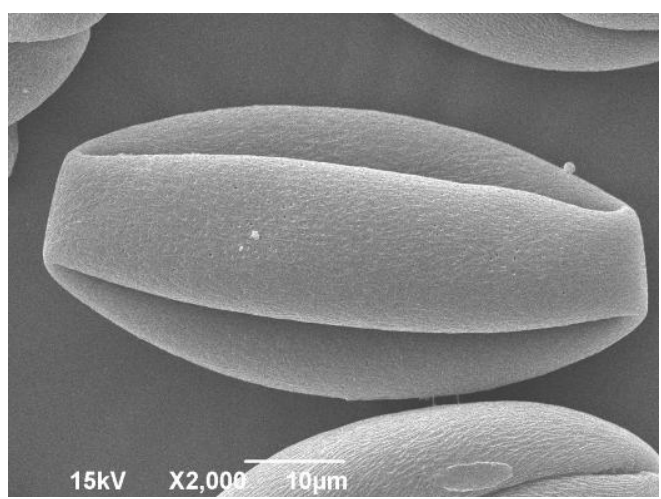

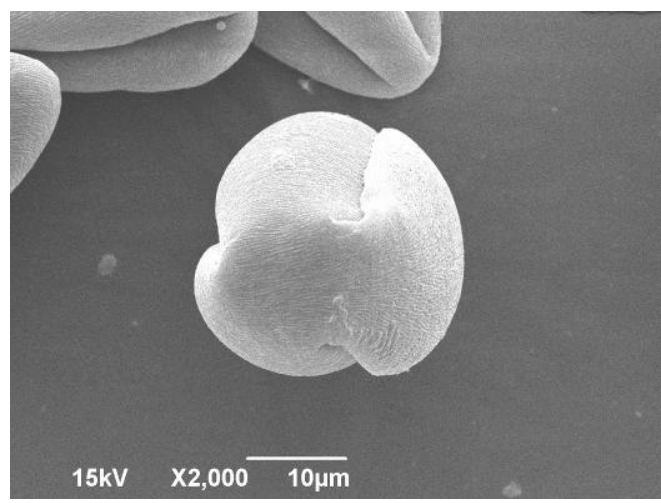
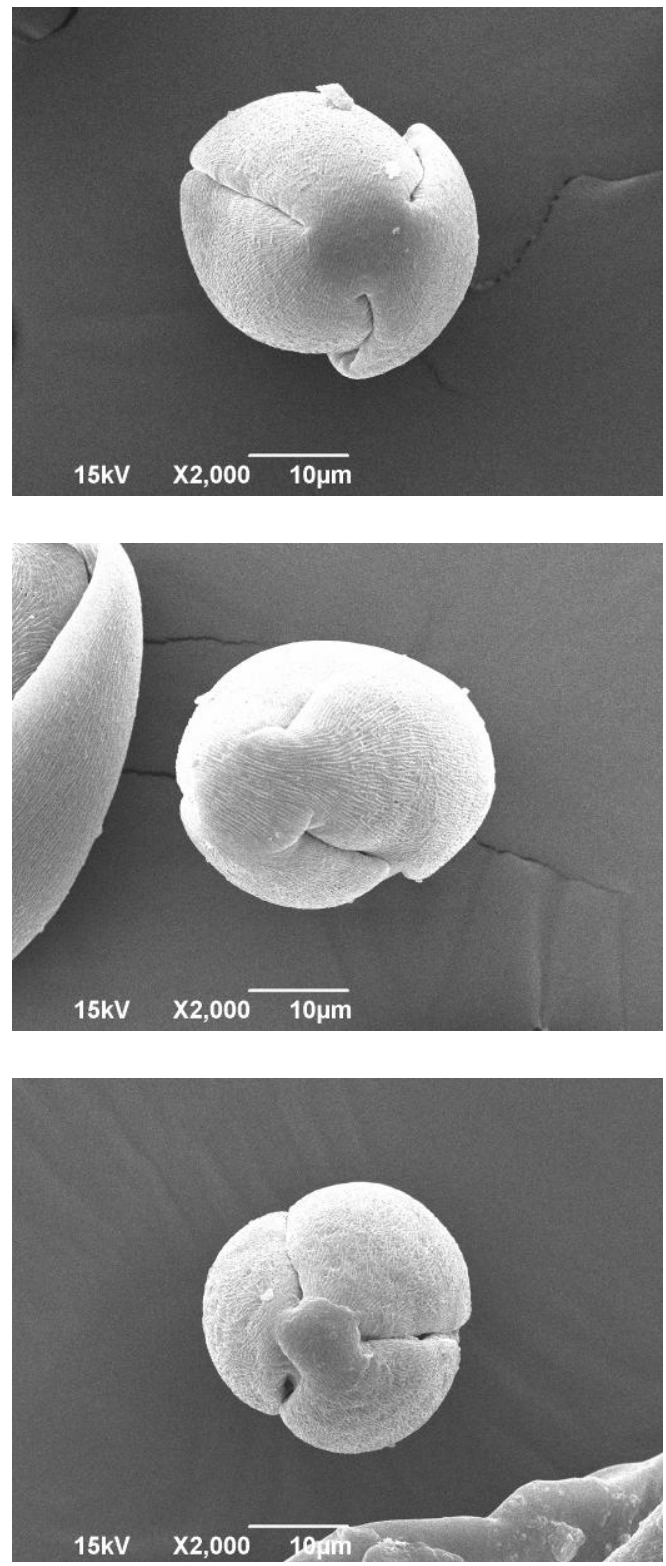

Figure 1. Pollen grain (equatorial view $=$ left and polar view $=$ right $)$ in quince $($ Cydonia oblonga Mill. $)$ cultivars: a) Leskovacka, b) Vranjska, c) Morava, and d) Pazardzijska. 
a
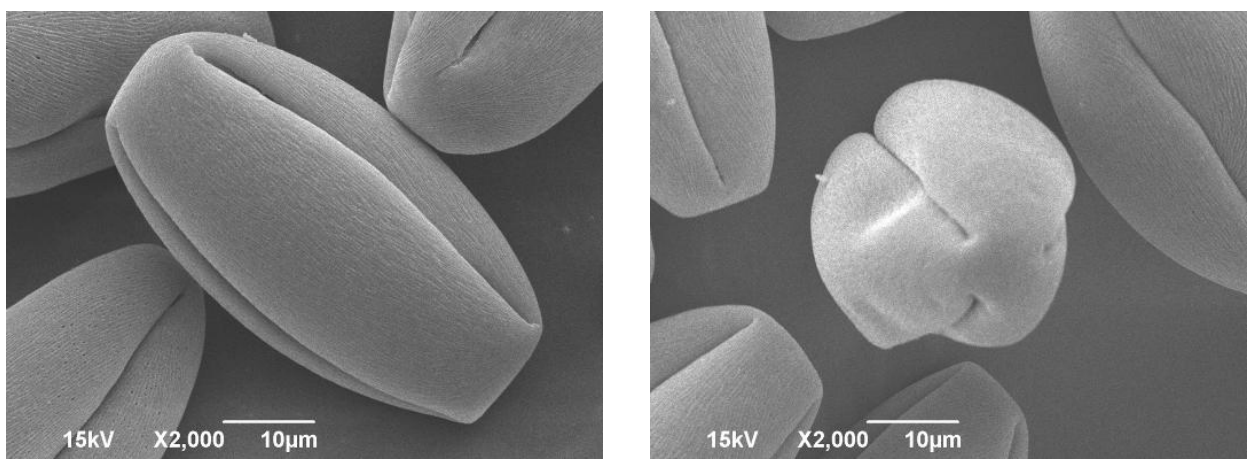

b
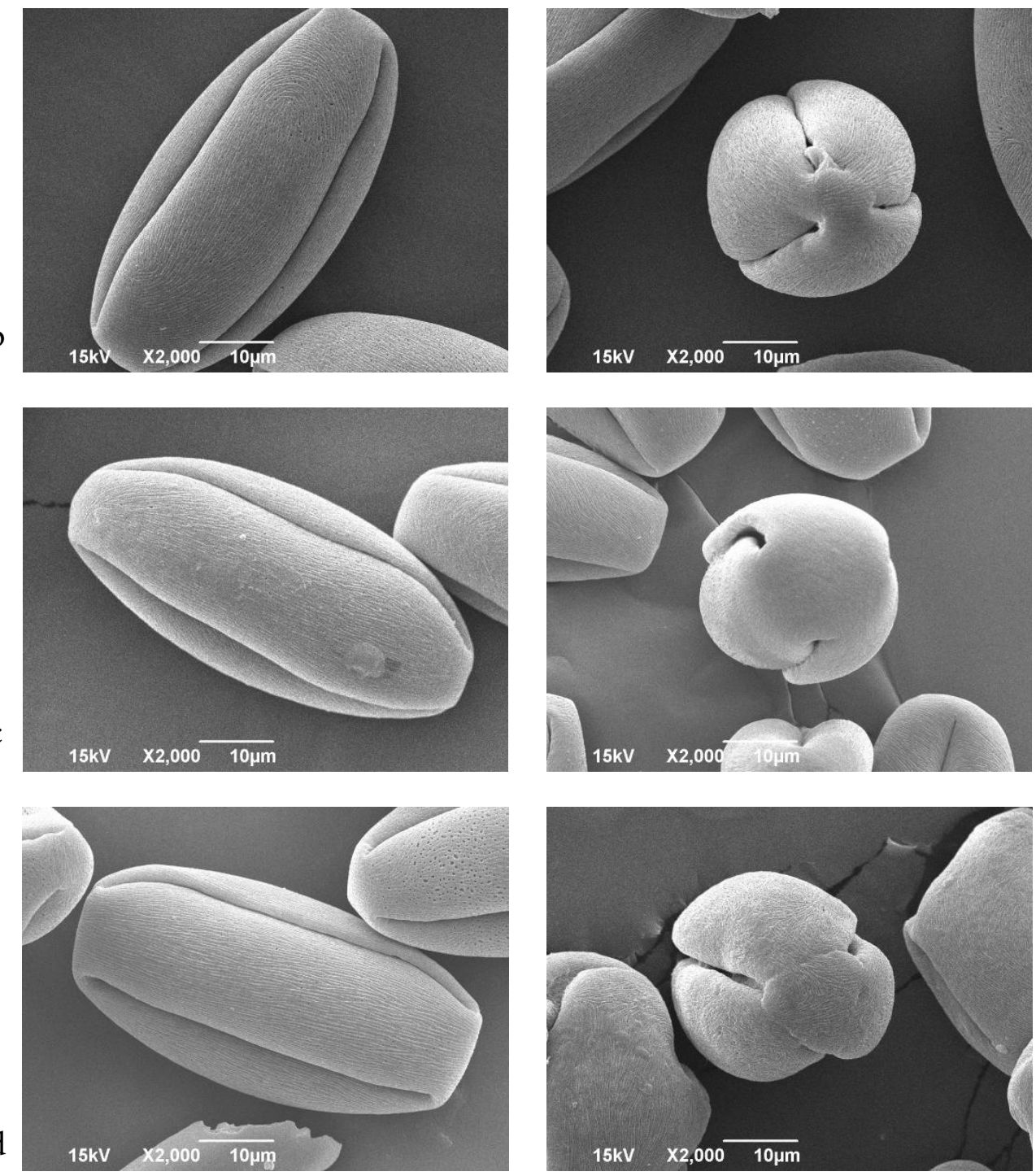

Figure 2. Pollen grain (equatorial view $=$ left and polar view $=$ right $)$ in quince $($ Cydonia oblonga Mill.) cultivars: a) Hemus, b) Asenica, c) Portugal, and d) Triumph.

the maximum length of pollen grains was determined in the Portugal cultivar $(56.05 \mu \mathrm{m})$ and the lowest in the Triumph cultivar $(53.08 \mu \mathrm{m})$ (Table 1). The width of pollen grains ranged from $26.66 \mu \mathrm{m}$ (Triumph) to $27.94 \mu \mathrm{m}$
(Pazardzijska). In relation to the results that were found by Evrenosoğlu and Misırlı (2009), the values obtained in our studies were higher in all cultivars for the length of the pollen grain, while half of the investigated cultivars 
Table 1. Dimensions of pollen grains in quince (Cydonia oblonga Mill.) cultivars (average, 20102012).

\begin{tabular}{|l|l|l|l|}
\hline Cultivar & Pollen length $(\mu \mathrm{m})$ & Pollen width $(\mu \mathrm{m})$ & Length/width ratio \\
\hline Leskovacka & $53.47 \pm 0.49 \mathrm{~b}^{*}$ & $26.84 \pm 0.29 \mathrm{a}$ & $2.00 \pm 0.03 \mathrm{ac}$ \\
\hline Vranjska & $53.26 \pm 0.62 \mathrm{~b}$ & $27.87 \pm 0.54 \mathrm{a}$ & $1.94 \pm 0.03 \mathrm{bc}$ \\
\hline Morava & $53.17 \pm 0.41 \mathrm{~b}$ & $27.37 \pm 0.37 \mathrm{a}$ & $1.95 \pm 0.03 \mathrm{bc}$ \\
\hline Pazardzijska & $55.97 \pm 0.52 \mathrm{a}$ & $27.94 \pm 0.33 \mathrm{a}$ & $2.01 \pm 0.02 \mathrm{ac}$ \\
\hline Hemus & $53.21 \pm 0.59 \mathrm{~b}$ & $27.71 \pm 0.61 \mathrm{a}$ & $1.95 \pm 0.04 \mathrm{bc}$ \\
\hline Asenica & $54.10 \pm 0.35 \mathrm{~b}$ & $27.63 \pm 0.53 \mathrm{a}$ & $1.98 \pm 0.03 \mathrm{ac}$ \\
\hline Portugal & $56.05 \pm 0.44 \mathrm{a}$ & $27.46 \pm 0.31 \mathrm{a}$ & $2.05 \pm 0.02 \mathrm{a}$ \\
\hline Triumph & $53.08 \pm 0.53 \mathrm{~b}$ & $26.66 \pm 0.31 \mathrm{~b}$ & $2.00 \pm 0.03 \mathrm{ac}$ \\
\hline
\end{tabular}

${ }^{\star}$ Mean values followed by different lower-case letters in columns represent significant differences at $\mathrm{P}<0.05$, according to Tukey's test.

had higher values for the width of the pollen grains. This suggests that the dimensions of the pollen grain are to a large extent genetically determined, which can be of great importance for cultivar characterization. This is in accordance with the findings of Sótonyi et al. (2000). Structure of stigma and length and thickness of style can also be related to pollen size (Kirk, 1993). On the basis of the length-to-width ratio of the pollen grains, according to the classification given by Erdtman (1969), the shape of pollen grains varied from prolate (length/width $\leq 2$ ): Leskovacka, Vranjska, Morava, Hemus, Asenica, and Triumph, to perprolate (length/width $>2$ ): Pazardzijska and Portugal. In contrast to our results, Nagy-Dèri (2011) divided the investigated quince cultivars into two groups according to pollen shape: oblate $(\mathrm{P} / \mathrm{E}=0.5-0.75)$ and suboblate $(\mathrm{P} / \mathrm{E}=0.75-0.88)$ pollen grains.

Evrenosoğlu and Misirl (2009) point out that in the species of the family Rosaceae, length of pollen grains varies from $32.10 \mu \mathrm{m}$ to $59.45 \mu \mathrm{m}$ and width from 22.20 $\mu \mathrm{m}$ to $35.20 \mu \mathrm{m}$ depending on the species. In a more detailed analysis of morphological characteristics of the pollen of certain species within this family, the authors found a significantly greater average length and width of pollen grains in quince $(51.65 \mu \mathrm{m} ; 26.35 \mu \mathrm{m})$ compared to the other two pome fruit species (apple, $42.80 \mu \mathrm{m} ; 22.20$ $\mu \mathrm{m}$ and pear, $40.00 \mu \mathrm{m} ; 22.75 \mu \mathrm{m})$. Similar dimensions of pollen grains were found by other authors in apple and pear. The length of the pollen grain in apple ranged from $40.1 \mu \mathrm{m}$ to $43.8 \mu \mathrm{m}$ and width from $20.9 \mu \mathrm{m}$ to $23.2 \mu \mathrm{m}$ (Currie et al., 1997). In Japanese pear the length varied from $43.40 \mu \mathrm{m}$ to $45.08 \mu \mathrm{m}$ and the width from $21.80 \mu \mathrm{m}$ to $22.95 \mu \mathrm{m}$ (Matsuta et al., 1982).

Data for colpus and mesocolpium dimensions are shown in Table 2. Similar to the length of the pollen grain, the colpus length differed significantly among the examined cultivars. Colpus length was the highest in the

Table 2. Dimensions of the colpus and mesocolpium in quince (Cydonia oblonga Mill.) cultivars (average, 20102012).

\begin{tabular}{|l|l|l|l|}
\hline Cultivar & Colpus length $(\mu \mathrm{m})$ & Colpus width $(\mu \mathrm{m})$ & Mesocolpium width $(\mu \mathrm{m})$ \\
\hline Leskovacka & $46.82 \pm 0.60 \mathrm{~b}^{*}$ & $1.78 \pm 0.16 \mathrm{a}$ & $13.79 \pm 0.42 \mathrm{a}$ \\
\hline Vranjska & $46.49 \pm 0.79 \mathrm{~b}$ & $1.60 \pm 0.12 \mathrm{a}$ & $14.02 \pm 0.53 \mathrm{a}$ \\
\hline Morava & $45.93 \pm 0.47 \mathrm{~b}$ & $1.75 \pm 0.15 \mathrm{a}$ & $14.03 \pm 0.41 \mathrm{a}$ \\
\hline Pazardzijska & $48.92 \pm 0.64 \mathrm{a}$ & $1.41 \pm 0.09 \mathrm{a}$ & $13.32 \pm 0.46 \mathrm{a}$ \\
\hline Hemus & $46.89 \pm 0.51 \mathrm{~b}$ & $1.59 \pm 0.13 \mathrm{a}$ & $14.32 \pm 0.48 \mathrm{a}$ \\
\hline Asenica & $47.40 \pm 0.45 \mathrm{ab}$ & $1.78 \pm 0.14 \mathrm{a}$ & $14.70 \pm 0.57 \mathrm{a}$ \\
\hline Portugal & $48.81 \pm 0.51 \mathrm{a}$ & $1.85 \pm 0.11 \mathrm{a}$ & $14.78 \pm 0.55 \mathrm{a}$ \\
\hline Triumph & $46.08 \pm 0.54 \mathrm{~b}$ & $1.83 \pm 0.15 \mathrm{a}$ & $14.33 \pm 0.48 \mathrm{a}$ \\
\hline
\end{tabular}

${ }^{\star}$ Mean values followed by different lower-case letters in columns represent significant differences at $\mathrm{P}<0.05$, according to Tukey's test. 
cultivars Pazardzijska $(48.92 \mu \mathrm{m})$ and Portugal $(48.81 \mu \mathrm{m})$ and lowest in the cultivars Morava $(45.93 \mu \mathrm{m})$ and Triumph $(46.08 \mu \mathrm{m})$, which is related to length of the pollen grain. In contrast, the colpus and mesocolpium width were not statistically significantly different among the studied quince cultivars. Thus, the colpus and mesocolpium width ranged from $1.41 \mu \mathrm{m}$ and $13.32 \mu \mathrm{m}$ (Pazardzijska) to 1.85 $\mu \mathrm{m}$ and $14.78 \mu \mathrm{m}$ (Portugal), respectively.

The pattern of the exine of the investigated quince cultivars was striate, with longitudinal ridges (Figure 3), which agrees with the results obtained by Evrenosoğlu and Misirli (2009). The ridges were more parallel in the Vranjska, Hemus, Portugal, and Triumph cultivars and less parallel in the cultivars Leskovačka, Morava, Pazardzijska, and Asenica. In Vranjska, Hemus, Asenica, and Portugal cultivars, perforation of the exine was more pronounced compared to other cultivars. Comparing exine patterns of quince with apple and pear, Evrenosoğlu and Misırlı (2009) found that the ridges on the pollen surface in quince are less clear. In addition, perforations in the quince are unevenly distributed across the surface of pollen and are "in" and "on" the grooves. The authors further indicate the difference in perforation of the exine among the different cultivars of quince, which are higher in cultivar Ekmek compared to the cultivar Limon. In addition, there have been differences among cultivars of quince in the form of ridges and number and size of perforates on the exine.

Characteristics of the exine of pollen grains in quince cultivars, such as the number of ridges per $100 \mu \mathrm{m}^{2}$ of the equatorial regions of exine and ridge and furrow width, are shown in Table 3. The number of ridges per $100 \mu \mathrm{m}^{2}$ of exine differs significantly among the cultivars and varied from 28.44 (Morava) to 31.11 (Vranjska). In contrast to these properties, ridge width did not significantly vary among cultivars, and it ranged from $0.19 \mu \mathrm{m}$ to $0.21 \mu \mathrm{m}$. Similarly, the furrow width was not significantly different among cultivars, and it was the largest in the Triumph cultivar $(0.23 \mu \mathrm{m})$ and lowest in the Leskovacka cultivar $(0.20 \mu \mathrm{m})$. Since the cultivars of quince in our work were not significantly different in terms of exine ornamentation it is not sufficiently specific to justify the determination of cultivars in this manner.
A dendrogram of studied quince cultivars is presented in Figure 4. Quince cultivars are connected in different ways, which shows the existence of certain hierarchical levels. Considering the values of the Euclidean distance and grouping, three groups of similar cultivars were created. Cultivars Leskovacka, Morava, and Triumph make the first group. Cultivars Leskovacka and Morava, which are in the same hierarchical level, have short pollen length, pollen width, and number of ridges per $100 \mu \mathrm{m}^{2}$ of exine area. Cultivar Triumph, which is connected with the previous two cultivars on a higher hierarchical level and belongs to the same group, differs from the other two cultivars because it has greater colpus width, mesocolpium width, number of ridges per $100 \mu \mathrm{m}^{2}$ of exine area, and furrow width. Cultivars Vranjska and Hemus, which are connected on the lowest hierarchical level together with cultivar Asenica, make a second group. Considering the cultivars from the first group, they have greater pollen width and number of ridges per $100 \mu \mathrm{m}^{2}$ of exine area. The third group includes cultivars Pazardzijska and Portugal. Common for both cultivars is greater pollen length, length-to-width ratio, and colpus length. These three characteristics that make them differ from the other cultivars influenced their classification into a special group.

The analysis of morphological characteristics of pollen showed significant differences among quince cultivars concerning the dimensions of pollen grain (length, width, and their ratio) and colpus length. These properties are the most influential for classification of cultivars into particular groups. The pollen of the investigated cultivars was three-colpate. The shape of the pollen grains ranged from prolate to perprolate. The pattern of the exine of all cultivars was striate, with more or less parallel longitudinal ridges. Among these morphological characteristics of pollen, the most important for the determination of quince cultivars are the size and shape of pollen grains and the colpus length.

\section{Acknowledgments}

This study was supported by the Ministry of Education, Science, and Technological Development of the Republic of Serbia through the project TR 31063 and EU Commission Project AREA (no. 316004). 
RADOVIĆ et al. / Turk J Agric For

a

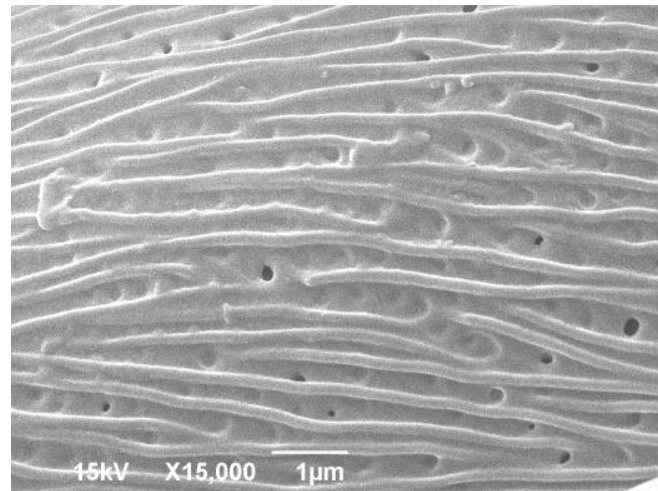

$\mathrm{C}$

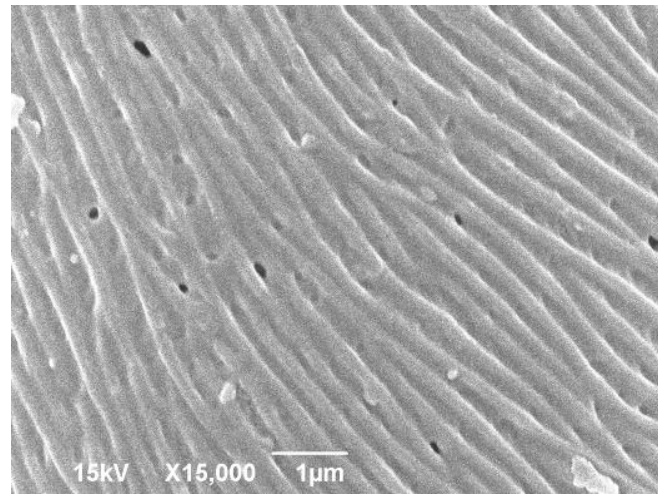

e

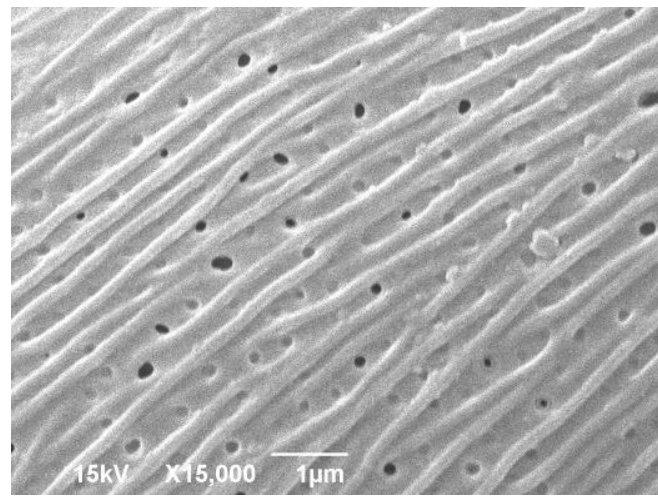

g

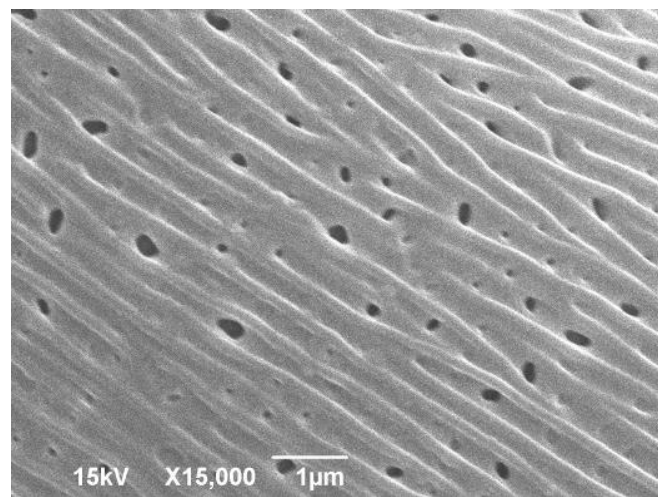

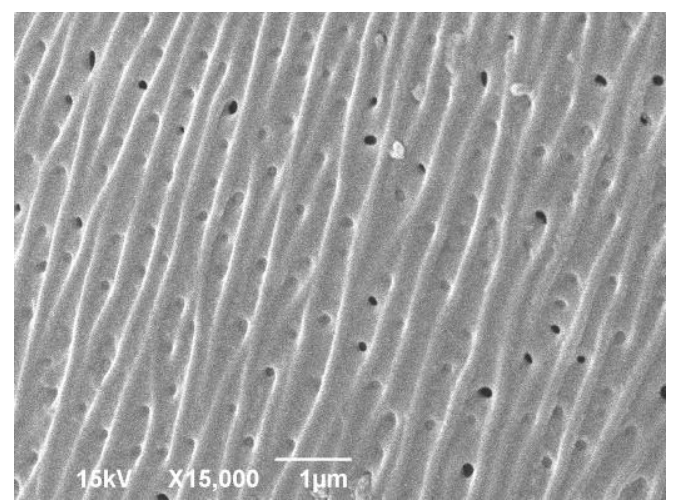

b
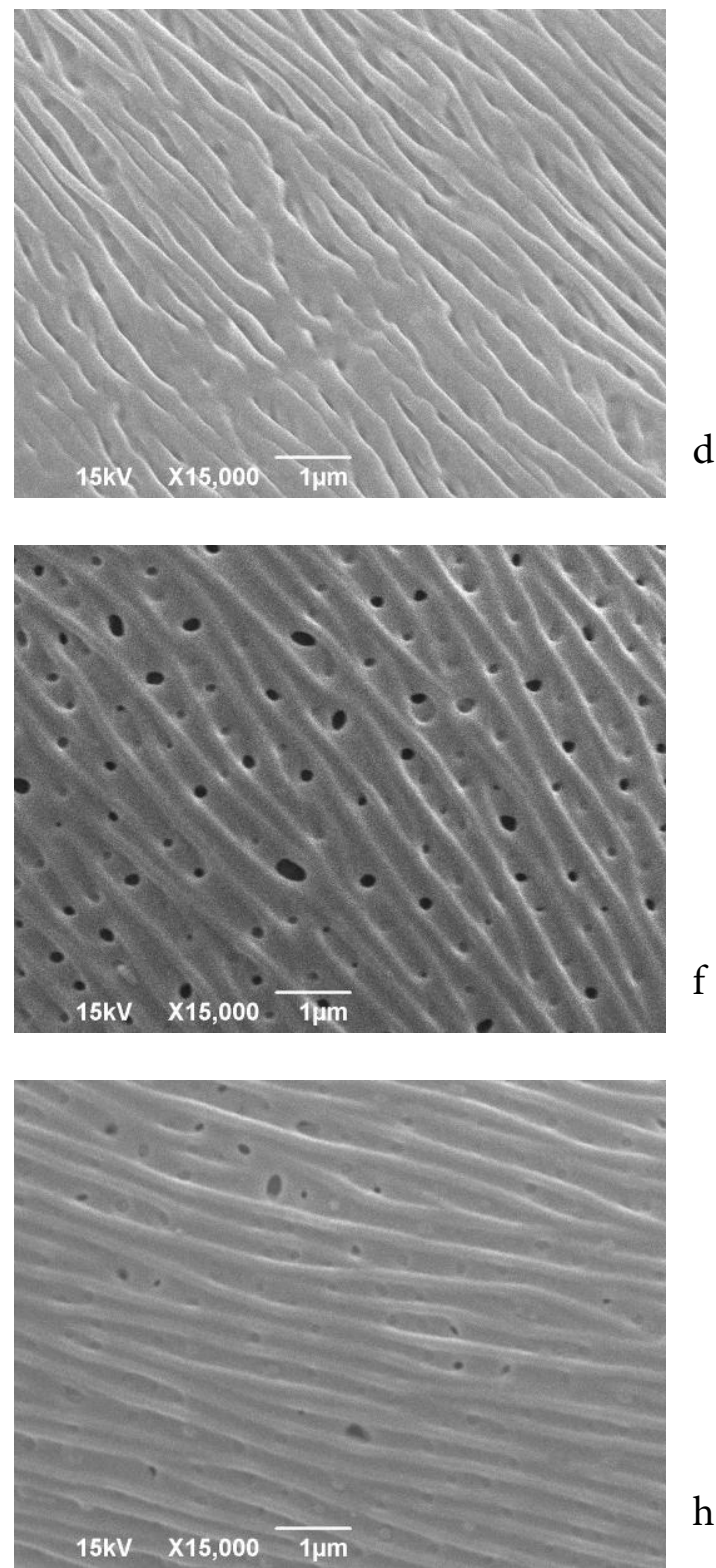

$\mathrm{h}$

Figure 3. Pollen exine pattern in quince (Cydonia oblonga Mill.) cultivars: a) Leskovacka, b) Vranjska, c) Morava, d) Pazardzijska, e) Hemus, f) Asenica, g) Portugal, and h) Triumph. 
Table 3. Exine pattern characteristics in quince (Cydonia oblonga Mill.) cultivars (average, 2010-2012).

\begin{tabular}{|l|l|l|l|}
\hline Cultivar & $\begin{array}{l}\text { No. of ridges per } \\
100 \mu \mathrm{m}^{2} \text { of exine area }\end{array}$ & $\begin{array}{l}\text { Ridge width } \\
(\mu \mathrm{m})\end{array}$ & $\begin{array}{l}\text { Furrow width } \\
(\mu \mathrm{m})\end{array}$ \\
\hline Leskovacka & $28.78 \pm 0.16 \mathrm{bd}^{*}$ & $0.19 \pm 0.003 \mathrm{a}$ & $0.20 \pm 0.006 \mathrm{a}$ \\
\hline Vranjska & $31.11 \pm 0.22 \mathrm{a}$ & $0.21 \pm 0.004 \mathrm{a}$ & $0.21 \pm 0.005 \mathrm{a}$ \\
\hline Morava & $28.44 \pm 0.22 \mathrm{bde}$ & $0.20 \pm 0.001 \mathrm{a}$ & $0.21 \pm 0.005 \mathrm{a}$ \\
\hline Pazardzijska & $29.22 \pm 0.19 \mathrm{bcd}$ & $0.19 \pm 0.004 \mathrm{a}$ & $0.21 \pm 0.006 \mathrm{a}$ \\
\hline Hemus & $30.89 \pm 0.17 \mathrm{ac}$ & $0.19 \pm 0.004 \mathrm{a}$ & $0.21 \pm 0.003 \mathrm{a}$ \\
\hline Asenica & $30.44 \pm 0.16 \mathrm{ad}$ & $0.19 \pm 0.002 \mathrm{a}$ & $0.21 \pm 0.002 \mathrm{a}$ \\
\hline Portugal & $29.56 \pm 0.29 \mathrm{ad}$ & $0.20 \pm 0.004 \mathrm{a}$ & $0.21 \pm 0.004 \mathrm{a}$ \\
\hline Triumph & $29.89 \pm 0.22 \mathrm{ad}$ & $0.19 \pm 0.003 \mathrm{a}$ & $0.23 \pm 0.007 \mathrm{a}$ \\
\hline
\end{tabular}

${ }^{\star}$ Mean values followed by different lower-case letters in columns represent significant differences at $\mathrm{P}<$ 0.05 , according to Tukey's test.

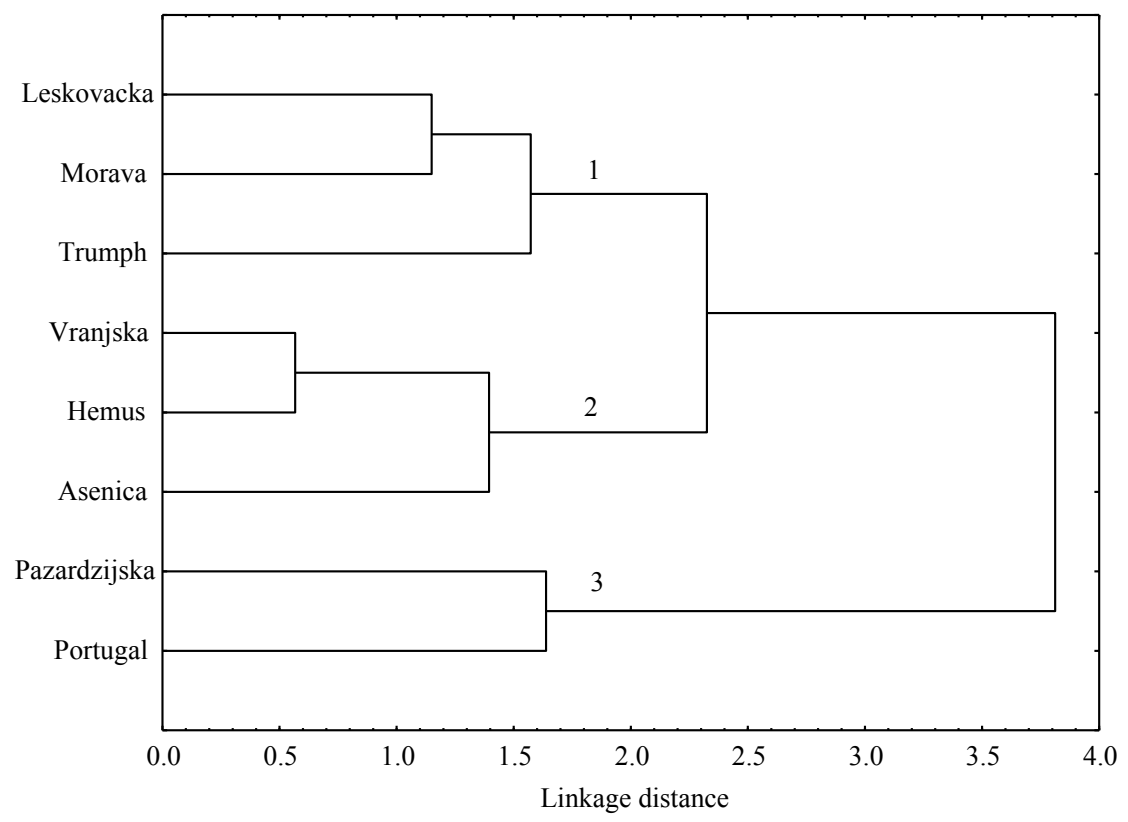

Figure 4. Dendrogram of eight quince cultivars constructed on the basis of the Euclidean distance matrix for all studied morphological characteristics of pollen grains.

\section{References}

Arzani K, Nejatian MA, Karimzadeh G (2005). Apricot (Prunus armeniaca) pollen morphological characterisation through scanning electron microscopy, using multivariate analysis. New Zeal J Crop Hort 33: 381-388.

Bell RL, Leitao JM (2011). Cydonia. In: Cole C, editor. Wild Crop Relatives-Genomic and Breeding Resources: Temperate Fruits. Berlin, Germany: Springer-Verlag, pp. 1-16.

Currie AJ, Noiton DA, Lawes GS, Bailey D (1997). Preliminary results of differentiating apple sports by pollen ultrastructure. Euphytica 98: 155-161.
Davarynejad GH, Rashed MH, Vatanpoor A, Csillag F (1995). The morphology of pollen grains as an indicator for identification of male pistachio (Pistacia vera L.) trees. Acta Hortic 419: 3742.

Dezhong T, Baoming W, Gaixiu D, Xiaofeng F (1995). Studies on the pollen morphology and ultrastructure of cultivated varieties of apricot, Armeniaca vulgaris Lam. Acta Hortic 403: 140-144.

Đokić A (1988). Biljna Genetika. Beograd, Serbia: Naučna knjiga (in Serbian). 
Edlund AF, Swanson R, Preuss D (2004). Pollen and stigma structure and function: the role of diversity in pollination. Plant Cell 16: S84-S97.

Erdtman G (1969). An Introduction to the Study of Pollen Grains and Spores. Copenhagen, Denmark: Munksgaard, pp. 486.

Evrenosoğlu Y, Misırlı A (2009). Investigations on the pollen morphology of some fruit species. Turk J Agric For 33: 181190.

Geraci A, Polizzano V, Marino P, Schicchi R (2012). Investigation on the pollen morphology of traditional cultivars of Prunus species in Sicily. Acta Soc Bot Pol 81: 175-184.

Gilani SA, Qureshi RA, Khan AM, Potter D (2010). Morphological characterization of the pollens of the selected species of genus Prunus Linn. from Northern Pakistan. Afr J Biotechnol 9: 2872-2879.

Hebda RJ, Chinnappa CC, Smith BM (1991). Pollen morphology of the Rosaceae of western Canada. IV. Luetkea, Oemleria, Physocarpus, Prunus. Can J Botany 69: 2583-2596.

Hu D, Fu J, Zhang Z (2012). Pollen morphology of ornamental peach cultivars. Acta Hortic 937: 845-849.

İnceoğlu Ö, Pınar NM, Oybak-Dönmez E (2000). Pollen morphology of wild Vitis sylvestris Gmelin (Vitaceae). Turk J Bot 24: 147150.

Joneghani VN (2008). Pollen morphology of the genus Malus (Rosaceae). Iran J Sci Technol A 32: 89-97.

Kaufmane E, Rumpunen K (2002). Sporogenesis and gametophyte development in Chaenomeles japonica (Japanese quince). Sci Hortic 94: 241-249.

Kirk WDJ (1993). Interspecific size and number variation in pollen grains and seeds. Biol J Linn Soc 49: 239-248.

Lanza B, Marsilio V (1999). Ultrastructural image analysis and biometric studies on pollen grain to distinguish olive cvs. Acta Hortic 474: 133-136.

Lanza B, Marsilio V, Martinelli N (1996). Olive pollen ultrastructure: characterization of exine pattern through image analysisscanning electron microscopy (IA-SEMI). Sci Hortic 65: 283294.

Lee U, Jung MS, Lee MH, Kang KN, Hyun JO, Kwon YH (2008). A consideration on the pollen morphology of walnut trees (Juglans spp.) by using scanning electron microscope (SEM). Korean J Apic 23: 139-145.

Matsuta N, Omura M, Akihama T (1982). Difference in micromorphological pattern on pollen surface of Japanese pear cultivars. Jpn J Breed 32: 123-128.
Mert C (2009). Pollen morphology and anatomy of cornelian cherry (Cornus mas L.) cultivars. HortScience 4: 519-522.

Mert C (2010). Anther and pollen morphology and anatomy in walnut (Juglans regia L.). HortScience 45: 757-760.

Miaja ML, Radicati L, Porporato M, Caramiello R, Fossa V, Vallania R (2000). Morpho-physiological observations on pollen of sour cherry (Prunus cerasus L.) cultivars. Acta Hortic 514: 311-320.

Mratinić E (2010). Dunja. Beograd, Serbia: Partenon (in Serbian).

Nagy-Dèri H (2011). Morphological investigations on anthers and pollen grains of some quince cultivars. Acta Biol Szeged 55: 231-235.

Nyéki J, Sótonyi P, Szabó Z, Felhosné Váczi E, Csillag F (1996). A scanning electron microscopy survey of pollen grains of sour cherry cultivars. Acta Hortic 410: 133-136.

Radice S, Ontivero M, Giordani E, Bellini E (2003). Morphology and physiology of pollen grains of Italian Prunus persica (L.) Batsch cultivars grown in Argentina. Adv Hort Sci 17: 93-96.

Radičević S, Nikolić D, Cerović R, Đorđević M (2013). In vitro pollen germination and pollen grain morphology in some sweet cherry (Prunus avium L.) cultivars. Rom Biotech Lett 18: 83418349 .

Ríos G, Tadeo FR, Leida C, Badene ML (2013). Prediction of components of the sporopollenin synthesis pathway in peach by genomic and expression analyses. BMC Genomics 14: 40 .

Roytchev V (2009). Application of cluster analysis and principal component analysis in palynobiometric studies of seedless cultivars and hybrid vine forms (Vitis vinifera L.). Bulg J Agric Sci 15: 31-40.

Shivanna KR (2003). Pollen biology and biotechnology. Enfield, NH, USA: Science Publishers, Inc.

Sorkheh K, Vezvaei A, Wirthensohn MG, Martínez-Gómez P (2008). Pollen ultrastructure characterization in Californian and Australian almond cultivars. J Am Pomol Soc 62: 173-177.

Sótonyi P, Szabó Z, Nyéki J, Benedek P, Soltész M (2000). Pollen morphology of fruit species. International Journal of Horticultural Science 6: 49-57.

Talaie A, Imani A (1998). Morphology of pollen grains as an index for identification of local Iranian almond varieties. Acta Hortic 470: $280-285$. 